\title{
Synthesis and characterization of novel rhenium(I) complexes towards potential biological imaging applications
}

\author{
Kokila Ranasinghe ${ }^{1}$, Shiroma Handunnetti ${ }^{2}$, Inoka C. Perera ${ }^{3}$ and Theshini Perera ${ }^{*}$ (1)
}

\begin{abstract}
Background: Re(I) tricarbonyl complexes exhibit immense potential as fluorescence imaging agents. However, only a handful of rhenium complexes have been utilized in biological imaging. The present study describes the synthesis of four novel rhenium complexes, their characterization and preliminary biological studies to assess their potential as biological imaging agents.

Results: Four facial rhenium tricarbonyl complexes containing a pyridyl triazine core, ( $L 1=5,5^{\prime}(3-(2-$-pyridyl)-1,2,4triazine-5,6-diyl)-bis-2-furansulfonic acid disodium salt and L2 = (3-(2- pyridyl)-5,6-diphenyl-1,2,4-triazine-4',4"'disulfonic acid sodium salt) have been synthesized by utilizing two different Re metal precursors, $\operatorname{Re}(\mathrm{CO})_{5} \mathrm{Br}$ and $\left[\mathrm{Re}(\mathrm{CO})_{3}\left(\mathrm{H}_{2} \mathrm{O}\right)_{3}\right] \mathrm{OTf}$ in an organic solvent mixture and water, respectively. The rhenium complexes $\left[\operatorname{Re}(\mathrm{CO})_{3}\left(\mathrm{H}_{2} \mathrm{O}\right)\right.$

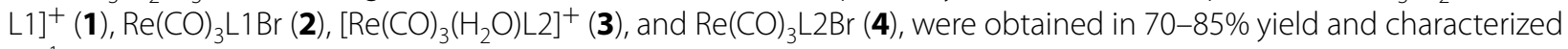
by ${ }^{1} \mathrm{H} N M R, I R, U V$, and luminescence spectroscopy. In both $\mathrm{H}_{2} \mathrm{O}$ and acetonitrile, complexes display a weak absorption band in the visible region which can be assigned to a metal to ligand charge transfer excitation and fluorescent emission lying in the 650-710 nm range. Cytotoxicity assays of complexes $\mathbf{1}, \mathbf{3}$, and $\mathbf{4}$ were carried out for rat peritoneal cells. Both plant cells (Allium cepa bulb cells) and rat peritoneal cells were stained using the maximum non-toxic concentration levels of the compounds, $20.00 \mathrm{mg} \mathrm{ml}^{-1}$ for $\mathbf{1}$ and $\mathbf{3}$ and $5.00 \mathrm{mg} \mathrm{ml}^{-1}$ for $\mathbf{4}$ to observe under the epifluorescence microscope. In both cell lines, compound concentrated specifically in the nuclei region. Hence, nuclei showed red fluorescence upon excitation at $550 \mathrm{~nm}$.
\end{abstract}

Conclusions: Four novel rhenium complexes have been synthesized and characterized. Remarkable enhancement of fluorescence upon binding with cells and visible range excitability demonstrates the possibility of using the new complexes in biological applications.

Keywords: Rhenium tricarbonyl, NMR spectroscopy, Cytotoxicity, Fluorescent

\section{Background}

Metal complexes possess unique properties such as radioactivity $[1,2]$, preferential binding to certain proteins or organelles [3-7], inertness [8], lower toxicity than the purely organic molecules [9] and special photophysical properties [10-13] which make them eligible for both therapeutic and diagnostic applications [14-18]. Twophoton absorption behavior of certain transition metal

\footnotetext{
*Correspondence: theshi@sjp.ac.lk

${ }^{1}$ Department of Chemistry, University of Sri Jayewardenepura, Nugegoda, Sri Lanka

Full list of author information is available at the end of the article
}

complexes containing conjugated ligands show high applicability in biological imaging [19, 20]. Specifically, rhenium(I) metal complexes have attracted special attraction over other metals as their chemical characteristics demonstrate better potentiality for biochemical applications [20-22]. Longer life times [13, 14], high photostability $[7,20]$ and large Stoke's shifts $[7,23]$ make them ideal candidates for either in vitro or in vivo visualization of biological processes [24, 25].Their visible light excitation minimizes the UV damage to cells whereas conjugation with proteins and lipids facilitate their compatibility with biological systems [26]. Since $\operatorname{Re}(\mathrm{I})$ has $\mathrm{d}^{6}$ electronic 
configuration at the outer most shell, it possesses a low spin coordination sphere in metal-ligand complexes. This spatial structure of the metal coordination sphere makes the Re metal ion kinetically inert towards ligand substitutions which mitigate the metal-DNA interactions $[20,26]$, hence heavy metal toxicity. In addition to the kinetic inertness, the common availability of the robust fac- $\left[\operatorname{Re}(\mathrm{CO})_{3}\right]^{+}$core as air stable $\mathrm{fac}-\left[\operatorname{Re}(\mathrm{CO})_{3}\left(\mathrm{H}_{2} \mathrm{O}\right)_{3}\right]^{+}$ has been identified as an advantage for target-specific radiopharmaceutical synthesis, since aqua ligands can be easily substituted by a variety of functional groups such a amines, phospines and thioles $[1,27]$.

Fluorescence imaging is a nondestructive method [28], and noted over other in vitro visualization methods due to not only the increasing availability of various biocompatible fluorophores [29] but also due to its features such as sensitivity [28] and spatial resolution [10]. The ability to visualize in vitro biological processes not only in individual live cells but also in sub cellular components [30] such as DNA [28], exemplify fluorescence staining among other imaging techniques. Many $\operatorname{Re}(\mathrm{I})$ carbonyl complexes synthesized in recent years exhibit luminescent properties $[7,14,20-24,26]$ which is believed to originate from the metal-to-ligand charge transfer (MLCT) transitions [20-22, 28]. As an example, many rhenium(I) polypyridine complexes studied by Lo et al. exhibit triplet metal-to-ligand charge transfer emission [7, 21, 31, 32]. Since these transitions are partially forbidden, the decay times for fluorescence occurring from $\operatorname{Re}(\mathrm{I})$ complexes are longer [28], which then makes them easily distinguishable from autofluorescence of the biological substances, the obstacle for many well-known fluorescent probes [26]. Furthermore, the larger Stoke's shifts and higher photostability of these metal complexes create the opportunity to prevent probe-probe overlapping which enables staining different subcellular components simultaneously [28]. In addition, experiments on molecular dynamics in microsecond timescale are now possible due to polarized emission ability $[23,28]$ of transition metal complexes such as Re.

The coordination chemistry of both Re and ${ }^{99 \mathrm{~m}} \mathrm{Tc}$ are similar and therefore Re metal-ligand complexes serve as model systems for ${ }^{99 \mathrm{~m}}$ Tc-ligand complexes [1, 27, 33, 34] which enables correlation between in vitro and in vivo imaging. This correlation has led to a pathway to understand the behavior of radiopharmaceuticals at subcellular levels [23]. Several other correlations [35, 36] originating from $\operatorname{Re}(\mathrm{I})$ metal complexes containing pharmaceuticals as ligands, are under investigation and successful concepts such as "single core multimodal probes" [11] have been established. Furthermore, beta emitting Re isotopes such as $\operatorname{Re}^{188}$ and $\operatorname{Re}^{186}$ possess the possibility to serve in therapeutic applications [33], thereby increasing the importance of structural and spectral characterization of novel complexes of the non radioactive istotope of rhenium.

During this study two water soluble ligands having conjugated aromatic systems, 5,5'(3-(2-pyridyl)-1,2,4triazine-5,6-diyl)-bis-2- furansulfonic acid disodium salt (L1) and 3-(2-pyridyl)-5,6-diphenyl-1,2,4-triazine-4',4" disulfonic acid sodium salt (L2) were utilized (Fig. 1), with the objective of promoting the permeability of complexes into cellular membranes. The hydrophilicity was retained to some extent by choosing their anionic form which made synthesis feasible in polar solvents. We report here the synthesis of four novel complexes utilizing two different rhenium precursors as illustrated in Fig. 2.

Even though various metal complexes have been synthesized, characterized, and identified in recent years, their potential applicability as fluorophores and their practical use as biochemical probes are at an infant stage due to limitations such as bio toxicity. Therefore, cytotoxicity of the synthesized compounds was analyzed for mammalian cells and the ability to act as microscopy stains were tested in both plant and mammalian cells.

\section{Results and discussion}

\section{Synthesis and spectroscopic properties}

Four rhenium tricarbonyl complexes containing L1 and L2 were synthesized (Fig. 2) in good yield by utilizing two different Re metal precursors, $\operatorname{Re}(\mathrm{CO})_{5} \mathrm{Br}$ and $\left[\operatorname{Re}(\mathrm{CO})_{3}\left(\mathrm{H}_{2} \mathrm{O}\right)_{3}\right] \mathrm{OTf}$, in an organic solvent mixture and in water, respectively.

The spectroscopic data obtained for each complex confirm the extent of purity of complexes as well as their photophysical properties. Strong peaks in the 2035 to $1880 \mathrm{~cm}^{-1}$ range in FTIR spectra obtained for metal complexes are characteristic to the three carbonyl peaks in the metal coordination sphere and confirm the presence of the $f a c-\operatorname{Re}(\mathrm{CO})_{3}^{+}$core [1]. A broad peak is obtained for complex $\left.\operatorname{Re}(\mathrm{CO})_{3} \mathrm{~L} 1\left(\mathrm{H}_{2} \mathrm{O}\right)\right]^{+}(\mathbf{1})$ at $1889 \mathrm{~cm}^{-1}$ indicating overlap of peaks as previously reported for similar $\operatorname{Re}(\mathrm{I})$ $(\mathrm{CO})_{3} \mathrm{~L}$ complexes where $\mathrm{L}=$ ethyl (bis(2-pyridylmethyl) amino)acetate [1] and $\mathrm{L}=2,4,6$-tris (2-pyridyl)-1,3,5-triazine [37]. The $\operatorname{Re}(\mathrm{CO})_{5} \mathrm{Br}$ metal precursor contains three peaks for vibrational stretching of carbonyl ligands in the 2034 to $1976 \mathrm{~cm}^{-1}$ range and the formation of complex 2 has shifted the collection of peaks to lower energy levels due to changes in the chemical environment. Similar shifts were observed in IR spectra of all four metal complexes compared to their metal precursors, which confirm the formation of novel bonds with ligands.

Further, purity of the dried residues of the complexes and ligands were confirmed by ${ }^{1} \mathrm{H}$ and ${ }^{13} \mathrm{C}$ NMR data. The assignment of signals was based on the chemical 
shifts, coupling patterns and splitting patterns of each peak. These assignments were further confirmed by the data from 2D NMR experiments for complexes $\mathbf{1}$ and $\mathbf{3}$ (Additional file 1). The significant difference between the spectra of the uncoordinated ligands and their rhenium bound complexes is the deshielding of the peaks, which is expected to be higher for protons closer to the metal atom, due to electron withdrawing inductive effects of $\operatorname{Re}(\mathrm{I})$. In the free ligand (L1/ferene), the pyridyl H6 signal is the most downfield doublet (8.85 ppm) consistent with its close proximity to pyridyl nitrogen. In the spectrum of the metal complex 1 , the $\mathrm{H6}^{\prime}$ signal appears even more downfield (9.24 ppm, Fig. 3) which confirms the metal-N1' bond formation. Several previously reported examples have illustrated the ability of $\operatorname{Re}(\mathrm{I})$ metal ion to form five membered rings with ligands containing the bipyridyl core [12, 26, 38]. The same ring formation, without any rotational confirmations has been observed between Pt and ligands containing the pyridyl triazine core, of which the chemical structures have been confirmed by crystallographic data [8]. Thus, the metal complexes of this study were expected to bond with ligands by forming five membered rings with $\mathrm{N} 2$ and $\mathrm{N} 1$ ' nitrogen atoms. All the proton peaks of the ligand were further deshielded upon bond formation with $\operatorname{Re}(\mathrm{I})$ ion in complex 1 (Fig. 3) and support the proposed chemical structure. Fural protons give four closely spaced doublets within the 7.10-7.34 ppm range which also shift down field (7.15$7.52 \mathrm{ppm}$ ) upon metal bonding; however assignment of them by only using this information is not prudent and thus the fural signals have been collectively assigned for the purpose of this study. The spectra for complexes $\left[\operatorname{Re}(\mathrm{CO})_{3} \mathrm{~L} 1\left(\mathrm{H}_{2} \mathrm{O}\right)\right]^{+}(\mathbf{1})$ and $\operatorname{Re}(\mathrm{CO})_{3} \mathrm{~L} 1 \mathrm{Br}(\mathbf{2})$ bearing the same ligand, are similar except (almost negligible) extra peaks due to the presence of trace amounts of solvents and excess ligand in complex 2 . The coordination of bromide in complex 2 has been confirmed by ESI mass spectrometric analysis.

Even though the ${ }^{1} \mathrm{H}$ NMR spectrum of L2 (Fig. 4) is comparatively more complicated due to the presence of phenyl rings, the expected chemical shifts over close proximity to pyridyl nitrogen were seen in a spectrum of the free ligand. The ${ }^{1} \mathrm{H}$ NMR spectra for complexes $\left[\operatorname{Re}(\mathrm{CO})_{3} \mathrm{~L} 2\left(\mathrm{H}_{2} \mathrm{O}\right)\right]^{+}(3)$ and $\operatorname{Re}(\mathrm{CO})_{3} \mathrm{~L} 2 \mathrm{Br}(4)$ are very much similar to each other and the highest deshielding is exhibited by $\mathrm{H}^{\prime}$ and $\mathrm{H}^{\prime}$ as expected. This further deshielding can be attributed to the reduction of electron density in vicinity due to the bond formation of $\mathrm{Re}$ with pyridyl $\mathrm{N}$ atom. Unusual upfield shifts of the proton peaks attributed to $\mathrm{H}^{\prime}$ (8.53 and $\left.8.51 \mathrm{ppm}\right)$ and $\mathrm{H} 5^{\prime}$ (8.04 and $8.01 \mathrm{ppm}$ ) (Fig. 4) were observed in complexes 3 and 4 , respectively, in comparison with that of the uncoordinated ligand ( $\mathrm{H}^{\prime}: 8.81 \mathrm{ppm}$ and $\mathrm{H} 5^{\prime}$ : $8.27 \mathrm{ppm}$ ). Shielding of $\mathrm{H}^{\prime}$ and $\mathrm{H} 4^{\prime}$ protons upon metal-ligand bond formation may have occurred due to ring current effects or steric effects of the phenyl rings which tilt the N-Re$\mathrm{N}$ plane upon $\mathrm{N}$ coordination to Re. These upfield shifts were not observed in complexes with L1 which had fural rings (Fig. 3). However, upon coordination to Re, the $\mathrm{H} 4^{\prime}$ and $\mathrm{H}^{\prime}$ protons appear around similar values in all four complexes, irrespective of having fural or phenyl groups (Additional file 1: Table S1).

\section{UV visible and luminescence spectroscopy}

UV visible absorption spectra of all four complexes and of the two free ligands were measured in water at room temperature. Absorption spectra for uncoordinated ligands showed isolated bands at $342-325 \mathrm{~nm}$ for L1 and L2, respectively due to ligand centered transitions. The metal complexes showed two broad absorptions at comparatively longer wavelengths (Table 1, Additional file 1: Figures S1 and S2 of UV-VIS spectra in Additional file) in comparison with free ligands. The four new rhenium complexes<smiles>O=S(=O)(O[Na])c1ccc(-c2nnc(-c3ccccn3)nc2-c2ccccc2)o1</smiles><smiles>CS(=O)(=O)c1ccc(-c2nnc(-c3ccccn3)nc2-c2ccc(S(=O)(=O)O)cc2)cc1</smiles>

Fig. 1 Chemical structures of 5,5'(3-(2-pyridyl)-1,2,4-triazine-5,6-diyl)-bis-2-furansulfonic acid disodium salt (L1, left), and 3-(2-Pyridyl)-5,6-diphenyl1,2,4-triazine-4',4'"-disulfonic acid sodium salt (L2, right) 


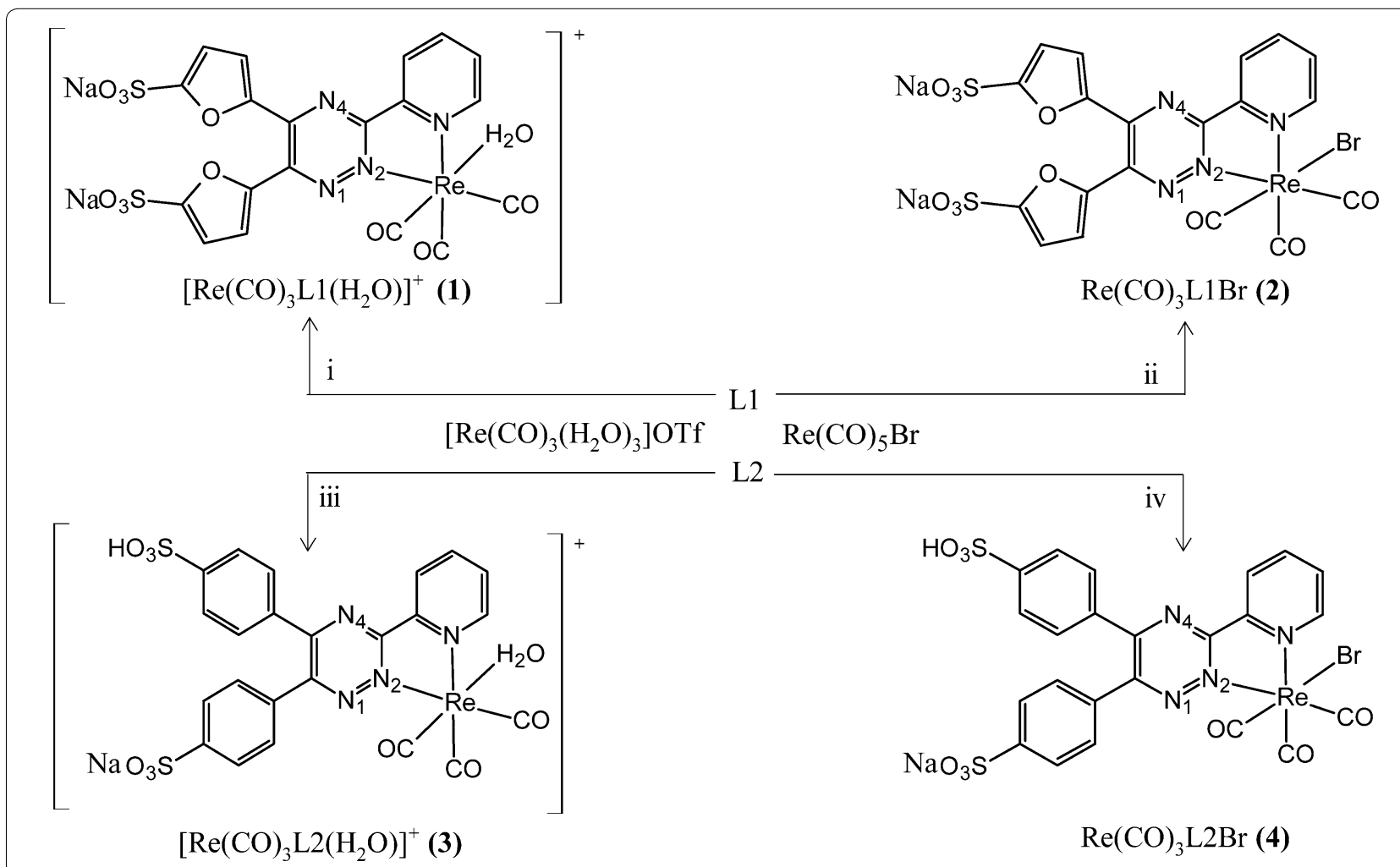

Fig. 2 Synthetic routes of complexes. (i) $4 \mathrm{~h}$ reflux in 10:1 acetonitrile:water mixture (ii) $0.16 \mathrm{~h}$ reflux in water (iii) $0.16 \mathrm{~h}$ reflux in water (iv). $8 \mathrm{~h}$ reflux in 7:2:1 acetonitrile:methanol:water mixture

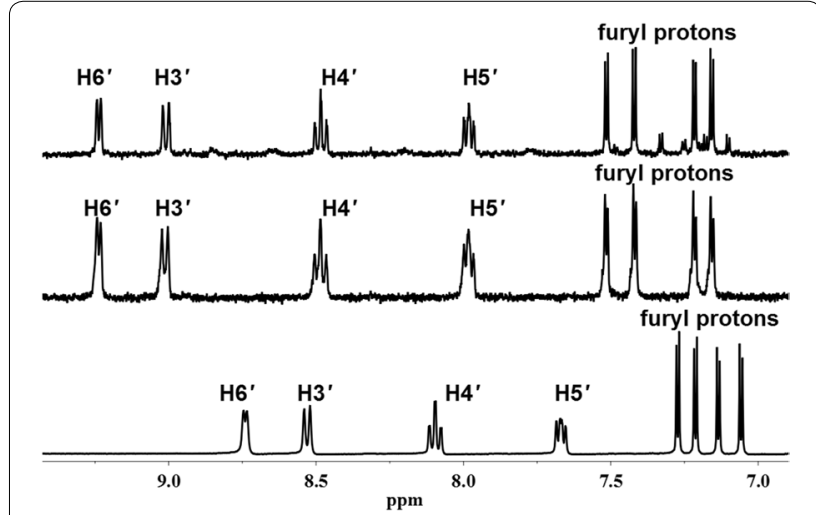

Fig. $3{ }^{1} \mathrm{H}$ NMR spectra of $\mathrm{L} 1$ (bottom), $\left[\operatorname{Re}(\mathrm{CO})_{3} \mathrm{~L}_{1}\left(\mathrm{H}_{2} \mathrm{O}\right)\right]^{+}$(1) (middle) and $\operatorname{Re}(\mathrm{CO})_{3} \operatorname{L} 1 \mathrm{Br}(\mathbf{2})$ (top) in $\mathrm{D}_{2} \mathrm{O}$ at $25^{\circ} \mathrm{C}$

fall into the special category, Metal-Ligand complex (MLCs) [28, 39]. According to previously reported studies, MLCs usually show closely associated, MLCT bands which are lower in energy than inter-ligand transitions (IL) [13, 39-43]. The absorption spectra of the new complexes are in agreement with this observation (Table 1); therefore the low energy bands for each complex can be assigned as MLCT. The emission spectra obtained for the new complexes show weak fluorescent bands in the visible region.
The visible range excitability of the novel complexes promises lesser damage in biological applications, when compared to most of the modern fluorescent imaging agents which need to be excited in the UV range.

\section{Bio-molecular probing ability}

Complexes, $\left[\operatorname{Re}(\mathrm{CO})_{3} \mathrm{~L} 1\left(\mathrm{H}_{2} \mathrm{O}\right)\right]^{+}(\mathbf{1}),\left[\operatorname{Re}(\mathrm{CO})_{3} \mathrm{~L} 2\left(\mathrm{H}_{2} \mathrm{O}\right)\right]^{+}$ (3), and $\operatorname{Re}(\mathrm{CO})_{3} \mathrm{~L} 2 \mathrm{Br}(4)$ are highly soluble in both water and PBS-BSA medium which makes them eligible to be used in in vitro biological experiments. Each complex was tested for cytotoxicity using Trypan blue staining method and none of them were considerably toxic to rat peritoneal cells up to reasonable concentrations which is a desired character of a biological imaging agent. Complexes 1 and 3 are nontoxic up to $20.00 \mathrm{mg} / \mathrm{ml}$ concentrations. However $\operatorname{Re}(\mathrm{CO})_{3} \mathrm{~L} 2 \mathrm{Br}$ (4) showed relatively higher toxicity than complexes $\mathbf{1}$ and $\mathbf{3}$. This excessive toxicity may be attributed to the presence of $\mathrm{Br}$ atom in complex $\operatorname{Re}(\mathrm{CO})_{3} \mathrm{~L} 2 \mathrm{Br}(4)$, instead of a $\mathrm{H}_{2} \mathrm{O}$ molecule as in $\left[\operatorname{Re}(\mathrm{CO})_{3} \mathrm{~L} 1\left(\mathrm{H}_{2} \mathrm{O}\right)\right]^{+}(\mathbf{1})$ and $\left[\operatorname{Re}(\mathrm{CO})_{3} \mathrm{~L} 2\left(\mathrm{H}_{2} \mathrm{O}\right)\right]^{+}$ (3). Compounds bearing halogen groups have been reported to demonstrate higher toxicity when compared to the non-halogenated analogues [44]. We attribute the increased cytotoxicity of complex $\mathbf{4}$ to its increased lipophilicity in comparison with that of complex 3. 
In order to confirm the potential use of these Re complexes as fluorophores, their ability to act as microscopic stains was tested using plant cells (Allium cepa bulb cells) and rat peritoneal cells. Complexes were seen to be selectively bound to the nuclear region in the cells. Even though the complexes have shown weaker fluorescence in water itself, it has given sharp fluorescence images under the epifluorescence microscope system. We attribute this to increased conjugation or structural rigidity [45] after binding with cells which may have enhanced the fluorescence yield. According to Olmstead and co-workers [46], the fluorescent enhancement of certain substances upon binding occurs due to reduction of the rate of excited proton transfer to solvent molecules. However, further work should be carried out to confirm the exact reason of observed fluorescent enhancement.

\section{In vitro cytotoxicity}

There was no significant toxicity observed up to $20.00 \mathrm{mg} /$ $\mathrm{ml}$ concentrations of complexes $\left[\operatorname{Re}(\mathrm{CO})_{3} \mathrm{~L} 1\left(\mathrm{H}_{2} \mathrm{O}\right)\right]^{+}(\mathbf{1})$

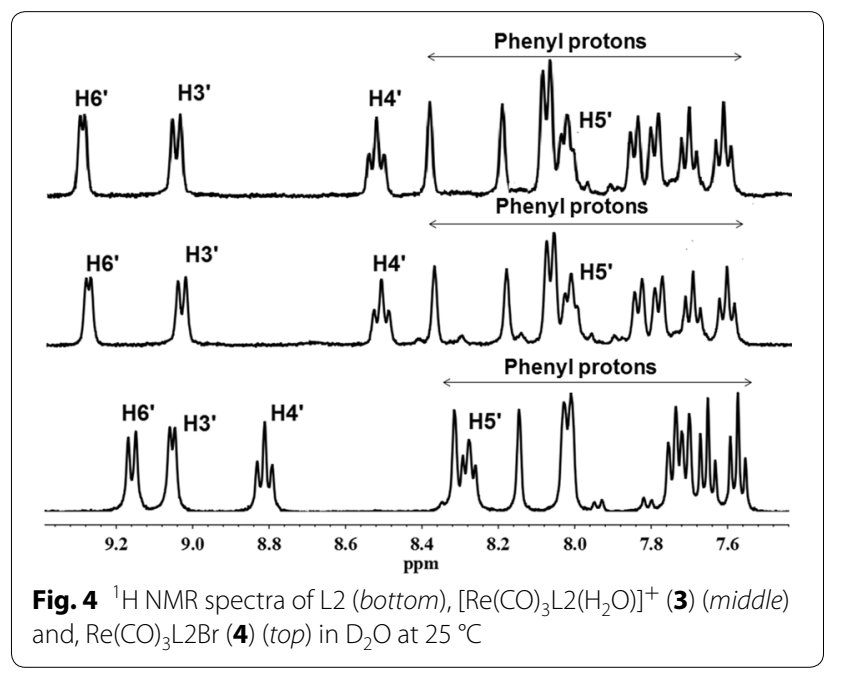

and $\left[\operatorname{Re}(\mathrm{CO})_{3} \mathrm{~L} 2\left(\mathrm{H}_{2} \mathrm{O}\right)\right]^{+}(3)$ in which the cell viability was in the range of 96 to $85 \%$ throughout the considered concentration range. However, complex $\operatorname{Re}(\mathrm{CO})_{3} \mathrm{~L} 2 \mathrm{Br}(4)$ was not tolerated by rat peritoneal cells at higher concentrations than $5.00 \mathrm{mg} \mathrm{ml}^{-1}$ at which the viability is $77 \%$ (Fig. 5).

Illumination of plant cells incubated with $\left[\operatorname{Re}(\mathrm{CO})_{3} \mathrm{~L} 2\left(\mathrm{H}_{2} \mathrm{O}\right)\right]^{+}(3)$ at $450 \mathrm{~nm}$ (blue color) resulted in weaker fluorescence images when compared to images taken at $550 \mathrm{~nm}$ (Fig. 6). This deviation from the results obtained by photo physical properties (MLCT excitation at $424 \mathrm{~nm}$ ) indicate that a novel binding mode may be involved between the complex and the cellular environment which has altered its fluorescent nature. Since the ligand itself does not result in any fluorescence image upon illumination at any of the above two wavelengths, it may be concluded that the novel binding of the metal complex with cells and also the enhanced luminescent properties originate originating from that binding occur solely due to the transition metal complex and not due to the ligand. Thus, $\left[\operatorname{Re}(\mathrm{CO})_{3} \mathrm{~L} 1\left(\mathrm{H}_{2} \mathrm{O}\right)\right]^{+}(\mathbf{1}),\left[\operatorname{Re}(\mathrm{CO})_{3} \mathrm{~L}_{2}\left(\mathrm{H}_{2} \mathrm{O}\right)\right]^{+}(\mathbf{3})$ and $\operatorname{Re}(\mathrm{CO})_{3} \mathrm{~L} 2 \mathrm{Br}(4)$ are suitable not only as biological imaging agents but also as model systems for ${ }^{99 \mathrm{~m}} \mathrm{Tc}$ complexes to enable complementary fluorescent and radioactive probe pairs which correlate in vitro and in vivo imaging studies.

The metal complexes are seen to associate with nuclei and this observation is confirmed by the images of stained plant cells in which only the nuclei show fluorescence (Fig. 6). Since rat peritoneal cells possess relatively larger nuclei the micrographs show gleaming of whole cells (Fig. 7).

Even though the compound $\left[\operatorname{Re}(\mathrm{CO})_{3} \mathrm{~L} 1\left(\mathrm{H}_{2} \mathrm{O}\right)\right]^{+}(\mathbf{1})$ has not shown relatively good photo physical properties in solution, after binding with cells its conjugation may have altered to result in better fluorescence properties. Ethidium bromide, a well-known fluorophore, was used as the positive control within the experiment. Even though these complexes do not give as sharp images as

Table 1 Electronic, emission spectral data of complexes 1-4 in $\mathrm{H}_{2} \mathrm{O}$ at $25^{\circ} \mathrm{C}$

\begin{tabular}{|c|c|c|c|c|}
\hline \multirow[t]{2}{*}{ Complex } & \multicolumn{2}{|c|}{ UV visible absorption/nm } & \multirow[t]{2}{*}{ Excitation/nm } & \multirow[t]{2}{*}{ Emission/nm } \\
\hline & Inter-ligand & MLCT & & \\
\hline${ }^{\mathrm{w}}\left[\operatorname{Re}(\mathrm{CO})_{3} \mathrm{~L} 1\left(\mathrm{H}_{2} \mathrm{O}\right)\right]^{+}(\mathbf{1})$ & 330 & 420 & 425 & 700 \\
\hline${ }^{\mathrm{a}}\left[\operatorname{Re}(\mathrm{CO})_{3} \mathrm{~L} 1\left(\mathrm{H}_{2} \mathrm{O}\right)\right]^{+}(\mathbf{1})$ & & & 470 & 710 \\
\hline${ }^{w} \operatorname{Re}(\mathrm{CO})_{3} \operatorname{L} 1 \operatorname{Br}(\mathbf{2})$ & 328 & 400 & 400 & $480^{b}, 658$ \\
\hline${ }^{\mathrm{w}}\left[\operatorname{Re}(\mathrm{CO})_{3} \mathrm{~L} 2\left(\mathrm{H}_{2} \mathrm{O}\right)\right]^{+}(\mathbf{3})$ & 315 & 395 & 441 & 672 \\
\hline${ }^{\mathrm{a}}\left[\operatorname{Re}(\mathrm{CO})_{3} \mathrm{~L} 2\left(\mathrm{H}_{2} \mathrm{O}\right)\right]^{+}(\mathbf{3})$ & & & 424 & 645 \\
\hline${ }^{w} \operatorname{Re}(\mathrm{CO})_{3} \mathrm{~L} 2 \mathrm{Br}(\mathbf{4})$ & 300 & 396 & 398 & 640 \\
\hline${ }^{\mathrm{a}} \operatorname{Re}(\mathrm{CO})_{3} \mathrm{~L} 2 \mathrm{Br}(\mathbf{4})$ & & & 396 & 645 \\
\hline
\end{tabular}

\footnotetext{
w In water

${ }^{a}$ In acetonitrile

${ }^{b}$ Peak due to excess ligand
} 
the positive control (Fig. 6), adequate amount of imaging potential can be seen in all three compounds.

\section{Experimental section Starting materials}

5,5'(3-(2-pyridyl)-1,2,4-triazine-5,6-diyl)-bis-2-furansulfonic acid disodium salt (ferene/L1), 3-(2-pyridyl)-5,6diphenyl-1,2,4-triazine- $4^{\prime}, 4^{\prime \prime}$-disulfonic acid sodium salt (L2), $\operatorname{Re}(\mathrm{CO})_{10}$, bromine water and AgOTf were obtained commercially from Sigma Aldrich and $\operatorname{Re}(\mathrm{CO})_{5} \mathrm{Br}$ and $\left[\operatorname{Re}(\mathrm{CO})_{3}\left(\mathrm{H}_{2} \mathrm{O}\right)_{3}\right] \mathrm{OTf}(\mathrm{OTf}=$ trifluoromethanesulfonate $)$ were prepared by known methods [47]. A $0.1 \mathrm{M}$ solution of $\left[\operatorname{Re}(\mathrm{CO})_{3}\left(\mathrm{H}_{2} \mathrm{O}\right)_{3}\right]$ OTf was used for the synthesis of the metal complexes and was prepared by carefully weighing $0.238 \mathrm{~g}$ of $\left[\mathrm{Re}(\mathrm{CO})_{5} \mathrm{OTf}\right]$ directly into the reaction vial, into which exactly $5000 \mu \mathrm{l}$ of water was pipetted out and heated at reflux for $30 \mathrm{~min}$. Analytical grade water and methanol purchased from Merck Specialties (Pvt) Limited and used as received. Carrageenan (Commercial grade-Type I) and Bovine Serum Albumin (BSA) were purchased from Aldrich and used as received. Phosphate buffered saline (1X PBS), $1 \mathrm{mg} / \mathrm{ml}$ PBS-BSA solution and $0.2 \%$ Trypan blue were prepared by known methods [48]. Healthy, white albino rats were selected from the animal house of the Department of Zoology and Environment Sciences, University of Colombo, Sri Lanka. Ethical clearance for extracting animal cells was obtained from the Research, Ethics and Higher Degrees Committee of the Institute of Biochemistry, Molecular Biology and Biotechnology of the University of Colombo and the experiments were performed according to internationally accepted guidelines for handling laboratory animals.

\section{NMR measurements}

${ }^{1} \mathrm{H},{ }^{13} \mathrm{C},{ }^{1} \mathrm{H}-{ }^{1} \mathrm{H}$ ROESY, and ${ }^{1} \mathrm{H}_{-}{ }^{13} \mathrm{C}$ HSQC $(400 \mathrm{MHz})$ NMR spectra were recorded in $\mathrm{D}_{2} \mathrm{O}$ on a Bruker spectrometer and all peak positions are relative to TSP. NMR data were processed with Mestre-C software.

\section{Mass spectrometric measurements}

High resolution mass spectra were recorded on an Agilent 6210 ESI TOF LCMS mass spectrometer.

\section{Synthesis of complexes}

\section{$\left[\operatorname{Re}(\mathrm{CO})_{3} L 1\left(\mathrm{H}_{2} \mathrm{O}\right)\right] \mathrm{OTf}(1)$}

A solution of $\left[\operatorname{Re}(\mathrm{CO})_{3}\left(\mathrm{H}_{2} \mathrm{O}\right)_{3}\right] \mathrm{OTf}(1 \mathrm{ml}, 0.1 \mathrm{mmol})$ and L1 $(0.0494 \mathrm{~g}, 0.1 \mathrm{mmol})$ in water $(5 \mathrm{ml})$ was refluxed for $16 \mathrm{~h}$. The resulting clear and bright red solution was cooled to room temperature and its volume reduced to give a fine red precipitate which was collected on a filter and dried (0.063 g 83\% yield). ${ }^{1} \mathrm{H}$ NMR $(\mathrm{ppm})$ in $\mathrm{D}_{2} \mathrm{O}: 9.24\left(\mathrm{~d}, \mathrm{H} 6^{\prime}\right)$, $9.02\left(\mathrm{~d}, \mathrm{H} 3^{\prime}\right), 8.49$ (t, H4'), 7.98 (t, H5'), 7.52-7.15 (fural H).

${ }^{13} \mathrm{C}$ NMR (ppm) in $\mathrm{D}_{2} \mathrm{O}: 199.2-193.6$ (CO), 166.6-148.3

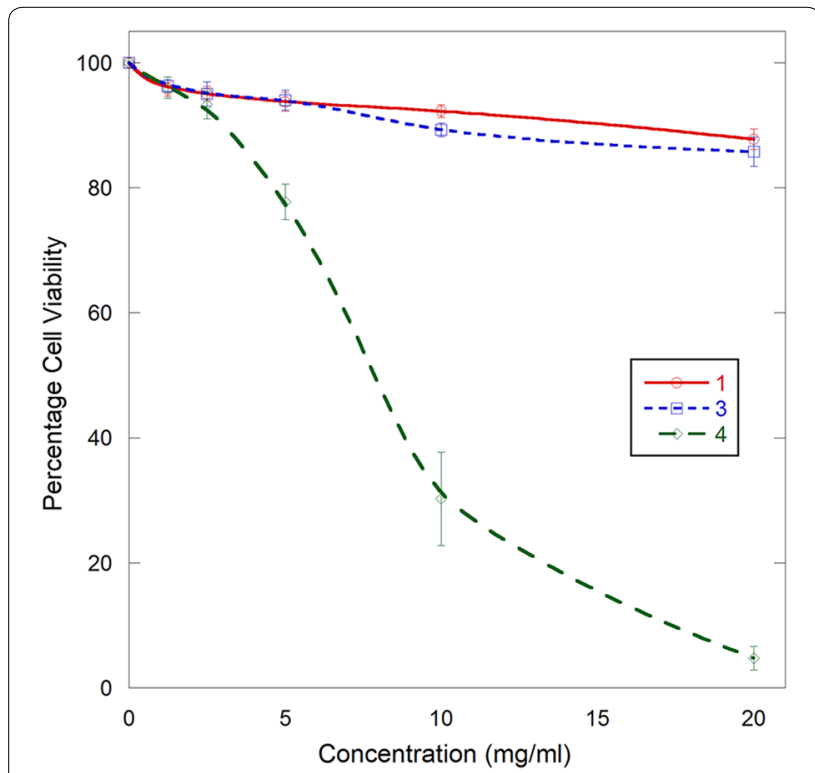

Fig. 5 Percentile viability of rat peritoneal cells incubated in compounds $\left[\operatorname{Re}(\mathrm{CO})_{3} \mathrm{~L} 1\left(\mathrm{H}_{2} \mathrm{O}\right)\right]^{+}(\mathbf{1}),\left[\operatorname{Re}(\mathrm{CO})_{3} \mathrm{~L}_{2}\left(\mathrm{H}_{2} \mathrm{O}\right)\right]^{+}(\mathbf{3})$ and $\operatorname{Re}(\mathrm{CO})_{3} \mathrm{~L} 2 \mathrm{Br}$ (4) at different concentrations

(triazine C), $157.7\left(\mathrm{C6}^{\prime}\right), 130.1\left(\mathrm{C}^{\prime}\right), 144.3\left(\mathrm{C}^{\prime}\right), 133.4$ (C5'), 116.5-121.2 (fural C). IR ( $\left.\mathrm{cm}^{-1}\right)$ : 2031, 1889 (CO). UV Vis $\left(\mathrm{nm}\right.$, in $\left.\mathrm{H}_{2} \mathrm{O}\right): 330$, 420. ESI-MS $(\mathrm{m} / z)$ : $[\mathrm{M}]^{-}$calcd for $\mathrm{C}_{19} \mathrm{H}_{10} \mathrm{~N}_{4} \mathrm{O}_{12} \operatorname{ReS}_{2}$, 734.9272; found, 734.9271.

\section{$\operatorname{Re}(\mathrm{CO})_{3} \operatorname{LiBr}(2)$}

A solution of $\operatorname{Re}(\mathrm{CO})_{5} \mathrm{Br}(0.0406 \mathrm{~g}, 0.1 \mathrm{mmol})$ and $\mathrm{L} 1$ $(0.0494 \mathrm{~g}, 0.1 \mathrm{mmol})$ in acetonitrile $(50 \mathrm{ml})$ and water $(5 \mathrm{ml})$ was heated at reflux for $4 \mathrm{~h}$. The resulting clear and deep red solution was cooled to room temperature and upon reducing its volume yielded a fine deep red precipitate which was collected on a filter and dried $(0.060 \mathrm{~g}$, $72 \%$ yield). ${ }^{1} \mathrm{H}$ NMR (ppm) in $\mathrm{D}_{2} \mathrm{O}: 9.25$ (d, H6'), 9.02 (d, $\mathrm{H} 3^{\prime}$ ), 8.48 (t, H4'), 7.99 (t, H5'), 7.52-7.16 (fural H). ${ }^{13} \mathrm{C}$ NMR (ppm) in $\mathrm{D}_{2} \mathrm{O}: 200.1-193.6$ (CO), 166.2-148.1 (triazine C), 157.6 (C6'), 130.2 (C3'), 144.3 (C4'), 133.3 (C5'), 116.5-126.0 (fural C). IR ( $\left.\mathrm{cm}^{-1}\right)$ : 2022, 1920, 1887 (CO). UV Vis (nm, in $\left.\mathrm{H}_{2} \mathrm{O}\right) 328,400$. ESI-MS $(\mathrm{m} / z)$ : [M] ${ }^{-}$calcd for $\mathrm{C}_{19} \mathrm{H}_{9} \mathrm{BrN}_{4} \mathrm{O}_{11} \mathrm{ReS}_{2}$, 796.8428; found, 796.8394 .

\section{$\left[\operatorname{Re}(\mathrm{CO})_{3} \mathrm{L2}\left(\mathrm{H}_{2} \mathrm{O}\right)\right] \mathrm{OTf}(3)$}

A solution of $\left[\operatorname{Re}(\mathrm{CO})_{3}\left(\mathrm{H}_{2} \mathrm{O}\right)_{3}\right] \mathrm{OTf}(1.000 \mathrm{ml}, 0.1 \mathrm{mmol})$ and $\mathrm{L} 2(0.0508 \mathrm{~g}, 0.1 \mathrm{mmol})$ in water $(5 \mathrm{ml})$ was refluxed for $16 \mathrm{~h}$. The resulting clear solution was cooled to room temperature and its volume reduced to give reddish orange crystals $(0.053 \mathrm{~g}, 70 \%) .{ }^{1} \mathrm{H}$ NMR (ppm) in $\mathrm{D}_{2} \mathrm{O}: 9.29$ (d, H6'), 9.05 (d, H3'), $8.53\left(\mathrm{t}, \mathrm{H} 4^{\prime}\right), 8.05\left(\mathrm{t}, \mathrm{H} 5^{\prime}\right), 8.39-7.62$ (phenyl H).). ${ }^{13} \mathrm{C}$ NMR (ppm) in $\mathrm{D}_{2} \mathrm{O}: 199.2-193.6$ (CO), 167.4146.6 (triazine $\mathrm{C}), 157.5\left(\mathrm{C6}^{\prime}\right), 130.5\left(\mathrm{C}^{\prime}\right), 144.5\left(\mathrm{C}^{\prime}\right), 132.5$ 


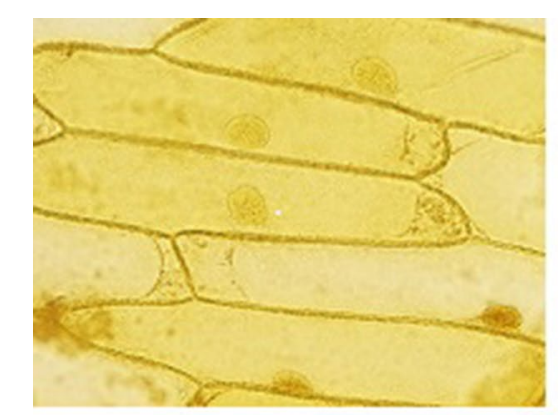

$\mathbf{a}$

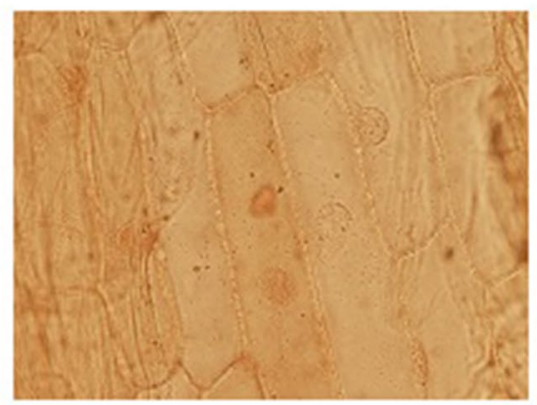

d

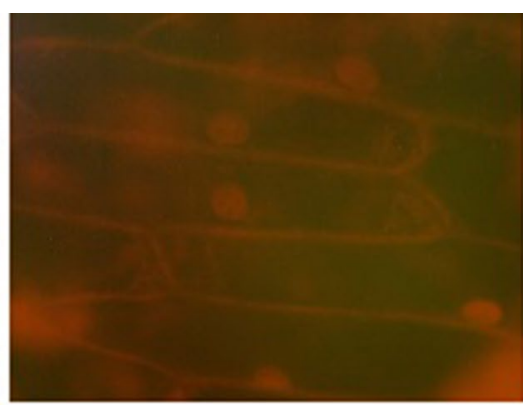

b

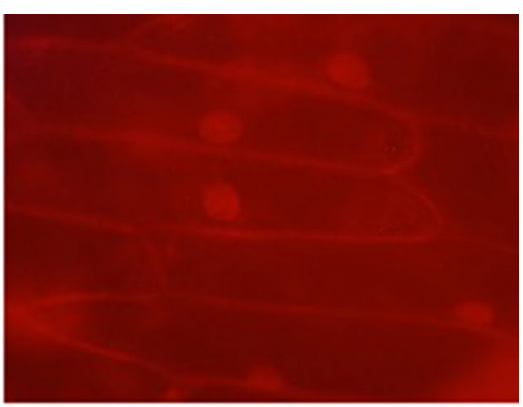

C

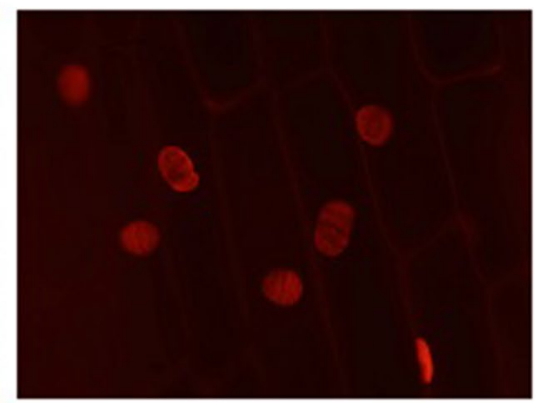

$\mathbf{e}$

Fig. 6 Allium Cepa bulb cells incubated with $20.00 \mathrm{mg} \mathrm{ml}^{-1}$ of $\left[\operatorname{Re}(\mathrm{CO})_{3} \mathrm{~L} 2\left(\mathrm{H}_{2} \mathrm{O}\right)\right]^{+}(\mathbf{3})$ in PBS-BSA solution under optical micrograph (a). Fluorescence micrographs of same cells excited at $450 \mathrm{~nm}$ (b), excited at $550 \mathrm{~nm}$ (c). Allium Cepa bulb cells incubated with ethidium bromide in PBS-BSA solution under optical micrograph (d). Fluorescence micrographs of same cells excited at $450 \mathrm{~nm}(\mathbf{e})$

(C5'), 129.7-136.9 (phenyl C). IR ( $\mathrm{cm}^{-1}$ ): 2023, 1897 (CO). UV Vis (nm, in $\left.\mathrm{H}_{2} \mathrm{O}\right) 315$, 395. ESI-MS $(\mathrm{m} / z)$ : $[\mathrm{M}]^{-}$calcd for $\mathrm{C}_{23} \mathrm{H}_{14} \mathrm{~N}_{4} \mathrm{O}_{10} \mathrm{ReS}_{2}$, 754.9686; found, 754.9695.

\section{$\operatorname{Re}(\mathrm{CO})_{3} \mathrm{~L} 2 \mathrm{Br}(4)$}

A solution of $\operatorname{Re}(\mathrm{CO})_{5} \mathrm{Br}(0.0406 \mathrm{~g}, 0.1 \mathrm{mmol})$ and L2 $(0.0508 \mathrm{~g}, 0.1 \mathrm{mmol})$ in a mixture of acetonitrile $(35 \mathrm{ml})$, methanol $(10 \mathrm{ml})$ and water $(5 \mathrm{ml})$ was heated at reflux for $8 \mathrm{~h}$. The resulting clear solution was cooled to room temperature and deep red crystals were obtained upon reducing its volume $\left(0.069 \mathrm{~g}, 82 \%\right.$ yield). ${ }^{1} \mathrm{H}$ NMR (ppm) in $\mathrm{D}_{2} \mathrm{O}: 9.27\left(\mathrm{~d}, \mathrm{H}^{\prime}\right), 9.03\left(\mathrm{~d}, \mathrm{H}^{\prime}\right), 8.51\left(\mathrm{t}, \mathrm{H} 4^{\prime}\right), 8.01(\mathrm{t}$, $\mathrm{H}^{\prime}$ ), 8.08-7.58 (phenyl $\mathrm{H}$ ). ${ }^{13} \mathrm{C}$ NMR (ppm) in $\mathrm{D}_{2} \mathrm{O}$ : 199.8-193.5 (CO), 166.2-148.1 (triazine C), 157.5 (C6'), 130.4 (C3'), $144.5\left(\mathrm{C}^{\prime}\right), 132.6\left(\mathrm{C}^{\prime}\right), 129.7-136.9$ (phenyl C). IR $\left(\mathrm{cm}^{-1}\right)$ : 2019, 1888 (CO). UV Vis (nm, in $\left.\mathrm{H}_{2} \mathrm{O}\right) 300$, 396. ESI-MS $(m / z)$ : $[\mathrm{M}]^{-}$calcd for $\mathrm{C}_{23} \mathrm{H}_{13} \mathrm{BrN}_{4} \mathrm{O}_{9} \mathrm{ReS}_{2}$, 816.8842; found, 816.882 .

\section{Photoluminescence measurements}

Emission spectra were recorded on a Thermoscientific Lumina Fluorescence spectrometer, using a $150 \mathrm{~W}$ Xenon Lamp as the excitation source. Data were processed with Luminous software.

\section{In vitro cytotoxicity assays}

Isolation of rat peritoneal cells was done as described previously [49]. Viability of the mammalian cells upon incubation in a mixture of $1 \mathrm{mg} \mathrm{ml}^{-1}$ PBS-BSA with each aqueous solution of complexes (due to the presence of trace amounts of solvent and excess ligand, complex 2 was not used in biological studies) for $30 \mathrm{~min}$ at $37^{\circ} \mathrm{C}$ was determined by the Trypan blue dye exclusion method using a hemocytometer (Neubauer-Germany). Viability of rat peritoneal cells in solutions of metal complexes at different concentrations were calculated with respect to the cell viability of the control sample and represented as the percentage of living cells \pm SEM (Standard Error of the Mean) where sample size is 4 (each experiment was repeated and each sample counting was done in duplicates).

\section{Fluorescence micrographs}

Stained plant and mammalian cells by incubating them in maximum tolerable concentrations $\left(20 \mathrm{mg} \mathrm{ml}^{-1}\right.$ solutions of complexes $\left[\operatorname{Re}(\mathrm{CO})_{3} \mathrm{~L} 1\left(\mathrm{H}_{2} \mathrm{O}\right)\right]^{+}(\mathbf{1})$ and $\left[\operatorname{Re}(\mathrm{CO})_{3} \mathrm{~L} 2\left(\mathrm{H}_{2} \mathrm{O}\right)\right]^{+}$ (3), $5 \mathrm{mg} \mathrm{ml}^{-1}$ solution of $\left.\operatorname{Re}(\mathrm{CO})_{3} \mathrm{~L} 2 \mathrm{Br}(4)\right)$ of aqueous solutions of complexes for $10 \mathrm{~min}$ at room temperature were observed under both optical and Olympus BX51 epifluorescence microscopes. Fluorescent micrographs were 


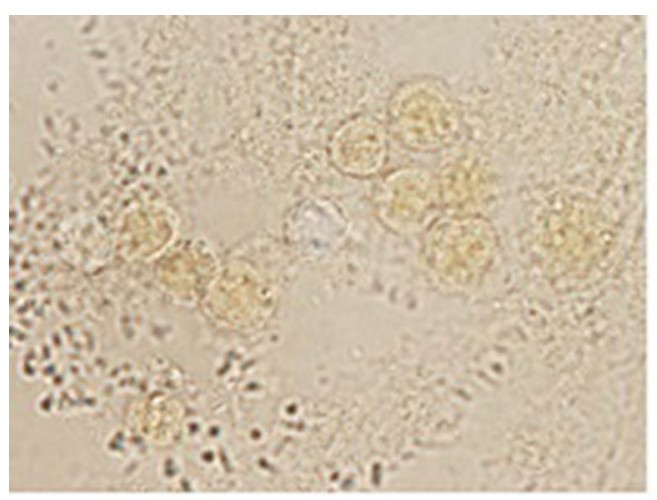

$\mathbf{a}$

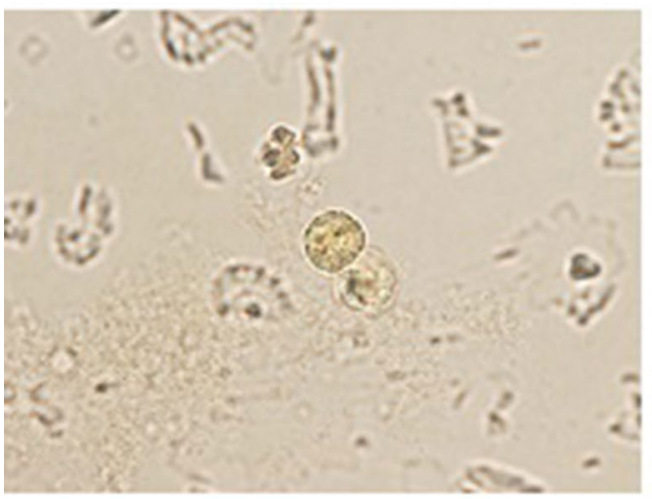

c

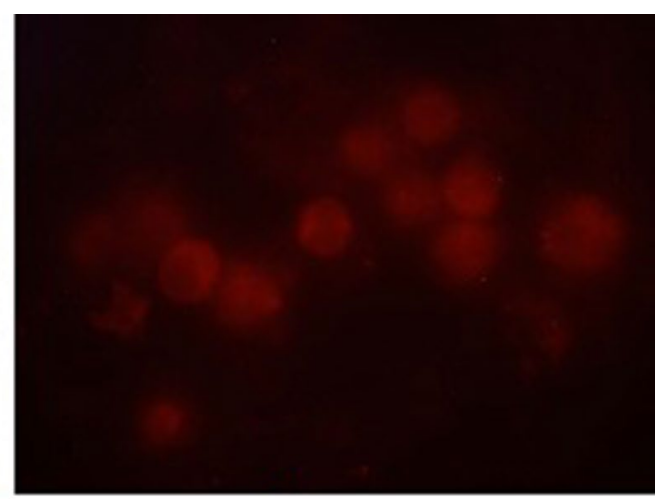

b

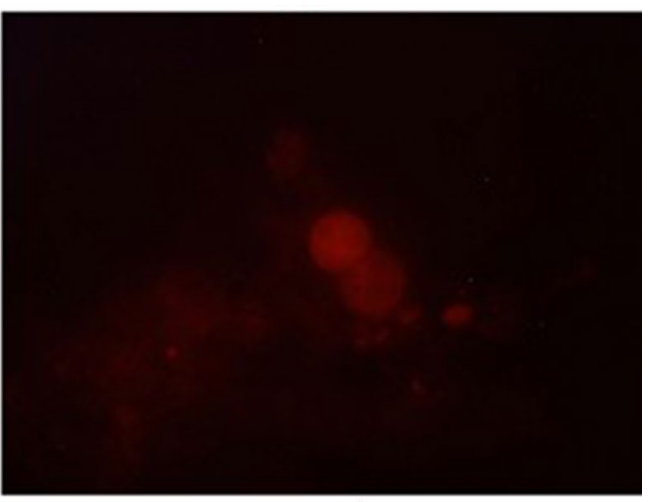

d

Fig. 7 Micrographs of rat peritoneal cells incubated with $20.00 \mathrm{mg} \mathrm{ml}^{-1}$ of $\left[\operatorname{Re}(\mathrm{CO})_{3} \mathrm{~L} 2\left(\mathrm{H}_{2} \mathrm{O}\right)\right]^{+}$(3) in PBS-BSA solution under optical microscope (a), under epifluorescence microscope $(\mathbf{b})$. Micrographs of rat peritoneal cells incubated with $20.00 \mathrm{mg} \mathrm{ml}^{-1} \mathrm{Of}\left[\mathrm{Re}(\mathrm{CO})_{3} \mathrm{~L} 1\left(\mathrm{H}_{2} \mathrm{O}\right)\right]^{+}(\mathbf{1})$ in $\mathrm{PBS}-\mathrm{BSA}$ solution under optical microscope $(\mathbf{c})$, under epifluorescence microscope $(\mathbf{d})$

obtained with the aid of Olympus DP70 and analyzed using Olympus Stream software.

\section{Conclusions}

Four rhenium complexes which showed good chemical stability in solution have been synthesized in good yield. NMR spectral characterization was utilized to ascertain the purity of complexes. Further characterization was done using UV-VIS, FTIR and emission spectra of all four complexes. The metal-ligand bond formation was clearly corroborated using UV-VIS absorption spectra since all four complexes exhibit an additional absorption band compared to ligand spectra which was assigned for MLCT transitions. These MLCT absorptions lie in 390 to $420 \mathrm{~nm}$ range. In addition FTIR spectra also provided supportive evidence for their purity and chemical stability with time. Photo physical properties indicate the fluorescent ability of complexes. Each complex showed emission within visible range from 600 to $700 \mathrm{~nm}$ providing large Stoke's shifts. However, complexes $\left[\operatorname{Re}(\mathrm{CO})_{3} \mathrm{~L} 1\left(\mathrm{H}_{2} \mathrm{O}\right)\right]^{+}(\mathbf{1})$ and $\operatorname{Re}(\mathrm{CO})_{3} \mathrm{~L} 2 \mathrm{Br}$ (4) only showed weak emissions in water where relatively better emissions were obtained in acetonitrile (Additional file 1: Table S1; Figures S1, S2).

Complexes $\left[\operatorname{Re}(\mathrm{CO})_{3} \mathrm{~L} 1\left(\mathrm{H}_{2} \mathrm{O}\right)\right]^{+}(\mathbf{1})$ and $\left[\operatorname{Re}(\mathrm{CO})_{3} \mathrm{~L} 2\right.$ $\left.\left(\mathrm{H}_{2} \mathrm{O}\right)\right]^{+}$(3) were nontoxic to rat peritoneal cells up to a high concentration, such as $20.00 \mathrm{mg} \mathrm{ml}^{-1}$ where $\operatorname{Re}(\mathrm{CO})_{3} \mathrm{~L} 2 \mathrm{Br}$ (4) was toxic to same cells above $5.0 \mathrm{mg} \mathrm{ml}^{-1}$ concentrations. However every complex, at its maximum nontoxic level showed excellent staining ability for both plant and rat peritoneal cells. The binding of the compound is believed to be occurring with the large nuclei of the cells. Even though the exact binding mode or the particular substance subjected to binding cannot be distinguished, the fluorescent yield of each compound seems to be increased after binding. Better micrographs were obtained when the stained cells excited at $550 \mathrm{~nm}$ and the emission occurred in red region. The obtained micrographs confirm the applicability of these novel rhenium complexes as biological imaging agents. 


\section{Additional file}

Additional file 1: Table S1. ${ }^{1} \mathrm{H}$ NMR chemical shifts (ppm) of complexes 1-4 in $\mathrm{D}_{2} \mathrm{O}$ at $25^{\circ} \mathrm{C}$. ${ }^{1} \mathrm{H}$ NMR chemical shifts (ppm) of complexes 1-4 in $\mathrm{D} 2 \mathrm{O}$ at $25^{\circ} \mathrm{C}$. Figure $\mathbf{S 1}$. UV VIS spectra of $\mathrm{L} 1$ (top), $\operatorname{Re}(\mathrm{CO})_{3} \mathrm{~L} 1 \mathrm{Br}(2$, middle) and $\left[\operatorname{Re}(\mathrm{CO})_{3} \mathrm{~L} 1\left(\mathrm{H}_{2} \mathrm{O}\right)\right]^{+}(1$, bottom). Figure S2. UV VIS spectra of $\mathrm{L} 2$ (top), $\left[\operatorname{Re}(\mathrm{CO})_{3} \mathrm{~L}_{2}\left(\mathrm{H}_{2} \mathrm{O}\right)\right]^{+}\left(3\right.$, middle) and $\operatorname{Re}(\mathrm{CO})_{3} \mathrm{~L} 2 \mathrm{Br}(4$, bottom). Figure S3. ${ }^{1} \mathrm{H}^{13} \mathrm{C}$ HSQC spectrum of a selected region of $\left[\operatorname{Re}(\mathrm{CO})_{3} \mathrm{~L} 1\left(\mathrm{H}_{2} \mathrm{O}\right)\right] \mathrm{OTf}(1)$ $\left(25^{\circ} \mathrm{C}, \mathrm{D}_{2} \mathrm{O}\right.$, shifts in ppm). Figure $\mathbf{S 4} .{ }^{1} \mathrm{H}-{ }^{1} \mathrm{H}$ ROESY spectrum of a selected region of $\left[\operatorname{Re}(\mathrm{CO})_{3} \mathrm{~L} 1\left(\mathrm{H}_{2} \mathrm{O}\right)\right] \mathrm{OTf}(1)\left(25^{\circ} \mathrm{C}, \mathrm{D}_{2} \mathrm{O}\right.$, shifts in ppm). Figure $\mathbf{S 5}$. ${ }^{1} \mathrm{H}-^{13} \mathrm{C} \mathrm{HSQC}$ spectrum of a selected region of $\left[\operatorname{Re}(\mathrm{CO})_{3} \mathrm{~L} 2\left(\mathrm{H}_{2} \mathrm{O}\right)\right] \mathrm{OTf}$ (3) (25 ${ }^{\circ} \mathrm{C}, \mathrm{D}_{2} \mathrm{O}$, shifts in ppm). Figure $\mathbf{S 6} .{ }^{1} \mathrm{H}-{ }^{1} \mathrm{H}$ ROESY spectrum of a selected region of $\left[\operatorname{Re}(\mathrm{CO})_{3} \mathrm{~L} 2\left(\mathrm{H}_{2} \mathrm{O}\right)\right] \mathrm{OTf}(3)\left(25^{\circ} \mathrm{C}, \mathrm{D}_{2} \mathrm{O}\right.$, shifts in ppm).

\section{Authors' contributions}

KR carried out the synthesis, purification, and characterization of the compounds as well as initial writing of manuscript. TP conceived the study and finalized the manuscript. SH and ICP designed the biological experiments and together with KR carried them out. All authors read and approved the final manuscript.

\section{Author details}

${ }^{1}$ Department of Chemistry, University of Sri Jayewardenepura, Nugegoda, Sri Lanka. ${ }^{2}$ Institute of Biochemistry, Molecular Biology and Biotechnology, University of Colombo, Colombo, Sri Lanka. ${ }^{3}$ Department of Zoology and Environmental Sciences, University of Colombo, Colombo, Sri Lanka.

\section{Acknowledgements}

The authors thank Prof. Luigi Marzilli and Dr. Pramuditha Abhayawardena of Louisiana State University for obtaining NMR data and for useful discussions. This work was partly funded by Grant No ASP/06/RE/SCI/2013/08 awarded by the University of Sri Jayewardenepura to TP.

\section{Competing interests}

The authors declare that they have no competing interests.

Received: 11 May 2016 Accepted: 10 November 2016

Published online: 25 November 2016

\section{References}

1. Banerjee SR, Levadala MK, Lazarova N, Wei L, Valliant JF, Stephenson KA et al (2002) Bifunctional single amino acid chelates for labeling of biomolecules with the $\left\{\mathrm{Tc}(\mathrm{CO})_{3}\right\}^{+}$and $\left\{\operatorname{Re}(\mathrm{CO})_{3}\right\}^{+}$Cores. crystal and molecular structures of $\left[\operatorname{ReBr}(\mathrm{CO})_{3}\left(\mathrm{H}_{2} \mathrm{NCH}_{2} \mathrm{C}_{5} \mathrm{H}_{4} \mathrm{~N}\right)\right],\left[\operatorname{Re}(\mathrm{CO})_{3}\left\{\left(\mathrm{C}_{5} \mathrm{H}_{4} \mathrm{NCH}_{2}\right)_{2} \mathrm{NH}\right\}\right]$ $\mathrm{Br},\left[\operatorname{Re}(\mathrm{CO})_{3}\left\{\left(\mathrm{C}_{5} \mathrm{H}_{4} \mathrm{NCH}_{2}\right)_{2 \mathrm{~N}} \mathrm{CH}_{2} \mathrm{CO}_{2} \mathrm{H}\right\}\right] \mathrm{Br},\left[\operatorname{Re}(\mathrm{CO})_{3}\left\{\mathrm{X}(\mathrm{Y}) \mathrm{NCH}_{2} \mathrm{CO}_{2} \mathrm{CH}_{2} \mathrm{CH}_{3}\right\}\right]$ $\mathrm{Br}(\mathrm{X}=\mathrm{Y}=2$-pyridylmethyl; $\mathrm{X}=2$-pyridylmethyl, $\mathrm{Y}=2$-(1-methylimidazolyl)methyl; $X=Y=2$-(1-methylimidazolyl)methyl), $\left[\operatorname{ReBr}(\mathrm{CO})_{3}\left\{\left(\mathrm{C}_{5} \mathrm{H}_{4} \mathrm{NCH}_{2}\right) \mathrm{NH}\left(\mathrm{CH}_{2} \mathrm{C}_{4} \mathrm{H}_{3} \mathrm{~S}\right)\right\}\right]$, and $\left[\mathrm{Re}(\mathrm{CO})_{3}\left\{\left(\mathrm{C}_{5} \mathrm{H}_{4} \mathrm{NCH}_{2}\right)\right.\right.$ $\left.\mathrm{N}\left(\mathrm{CH}_{2} \mathrm{C}_{4} \mathrm{H}_{3} \mathrm{~S}\left(\mathrm{CH}_{2} \mathrm{CO}_{2}\right)\right\}\right]$. Inorg Chem 41:6417-6425

2. Anderson CJ, Welch MJ (1999) Radiometal-labeled agents (non-technetium) for diagnostic imaging. Chem Rev 99(9):2219-2234

3. Ma R, Wang Y, Yan L, Ma L, Wang Z, Chan HC et al (2015) Efficient codelivery of $\mathrm{Pt}(\mathrm{IV})$ prodrug and $\mathrm{p} 53$ activator to enhance the anticancer activity of cisplatin. Chem Commun. 51(37):7859-7862

4. Brown DR, Qin K, Herms JW, Madlung A, Manson J, Strome R et al (1997) The cellular prion protein binds copper in vivo. Nature 390(6661):684

5. Bader CA, Brooks RD, Ng YS, Sorvina A, Werrett MV, Wright PJ et al (2014) Modulation of the organelle specificity in Re(I) tetrazolato complexes leads to labeling of lipid droplets. RSC Adv. 4(31):16345-16351

6. Andrepont C, Marzilli PA, Marzilli LG (2012) Guanine nucleobase adducts formed by [Pt(di-(2-picolyl)amine)Cl]Cl: evidence that a tridentate ligand with only in-plane bulk can slow guanine base rotation. Inorg Chem 51(21):11961-11970

7. Lo KK-W (2015) Luminescent Rhenium(I) and Iridium(III) polypyridine complexes as biological probes, imaging reagents, and photocytotoxic agents. Acc Chem Res 48(12):2985-2995
8. Maheshwari V, Bhattacharyya D, Fronczek FR, Marzilli PA, Marzilli LG (2006) Chemistry of HIV-1 virucidal pt complexes having neglected bidentate $\mathrm{sp}^{2} \mathrm{~N}$-donor carrier ligands with linked triazine and pyridine rings. synthesis, NMR spectral features, structure, and reaction with guanosine. Inorg Chem 45:7182-7190

9. Beraldo H, Gambinob D (2004) The wide pharmacological versatility of semicarbazones, thiosemicarbazones and their metal complexes. Mini Rev Med Chem. 4:31-39

10. Castellano FN, Malak H, Gryczynski I, Lakowicz JR (1997) Creation of metal-to-ligand charge transfer excited states with two-photon excitation. Inorg Chem 36:5548-5551

11. Cle 'de S, Lambert FO, Sandt C, Gueroui Z, Re'fre'giers M, Plamont M et al (2012) A rhenium tris-carbonyl derivative as a single core multimodal probe for imaging (SCOMPI) combining infrared and luminescent properties. J Chem Commun; 48:7729-31

12. Das S, Panda BK (2006) Synthesis and structure of luminescent $\operatorname{Re}^{\prime}(\mathrm{CO})_{3} \mathrm{Cl}$ complexes incorporating pyridyltriazine, pyrazinyltriazine and triazolopyridine chelation. Polyhedron 25:6

13. Kowalski K, Szczupak Ł, Bernaś T, Czerwieniec R (2015) Luminescent rhenium(I)-chromone bioconjugate: synthesis, photophysical properties, and confocal luminescence microscopy investigation. J Organomet Chem 782:124-130

14. Guo X, Castellano FN, Szmacinski H, Li L, Lakowicz JR, Sipior J (1997) A long-lived, highly luminescent Re(I) metal-ligand complex as a biomolecular probe. Anal Biochem 254:7

15. Lu G, Hillier SM, Maresca KP, Zimmerman CN, Eckelman WC, Joyal JL et al (2013) Synthesis and SAR of Novel Re ${ }^{99 \mathrm{~m}}$ Tc-labeled benzenesulfonamide carbonic anhydrase IX inhibitors for molecular imaging of tumor hypoxia. J Med Chem 56:510-520

16. Polyakov V, Sharma V, Dahlheimer JL, Pica CM, Luker GD, Piwnica-Worms D (2000) Novel tat-peptide chelates for direct transduction of technetium-99m and rhenium into human cells for imaging and radiotherapy. Bioconjugate Chem. 11(6):762-771

17. Moiseyenko VM, Dolmatov GD, Moiseyenko FV, Ivantsov AO, Volkov NM Chubenko VA (2015) High efficacy of cisplatin neoadjuvant therapy in a prospective series of patients carrying BRCA1 germ-line mutation. Med Oncol (Northwood, London, England) 32(4):514

18. Warra AA (2011) Transition metal complexes and their application in drugs and cosmetics. J Chem Pharm Res. 3:951-958

19. Baggaley E, Weinstein JA, Williams JAG (2012) Lighting the way to see inside the live cell with luminescent transition metal complexes. Coord Chem Rev 256(15-16):1762-1785

20. Fernandez-Moreira V, Thorp-Greenwood FL, Coogan MP (2010) Application of $\mathrm{d} 6$ transition metal complexes in fluorescence cell imaging. Chem Commun 46(2): 186-202

21. Lo KK-W, Choi AW-T, Law WH-T (2012) Applications of luminescent inorganic and organometallic transition metal complexes as biomolecular and cellular probes. Dalton Trans 41(20):6021-6047

22. Zhao Q, Huang C, Li F (2011) Phosphorescent heavy-metal complexes for bioimaging. Chem Soc Rev 40(5):2508-2524

23. Stephenson KA, Banerjee SR, Besanger T, Sogbein OO, Levadala MK, Mcfarlane N et al (2004) Bridging the gap between in vitro and in vivo imaging: isostructural Re and ${ }^{99 \mathrm{~m}} \mathrm{Tc}$ complexes for correlating fluorescence and radioimaging studies. एj Am Chem Soc 126(28):8598-8599

24. Shen Y, Maliwal BP, Lakowicz JR (2001) Long-lived luminescent Re(I) complexes containing cis-carbonyl and bidentate phosphine ligands. J Fluores. 11(4):315-318

25. Thorp-Greenwood FL (2012) An Introduction to organometallic complexes in fluorescence cell imaging: current applications and future prospects. Organometallics 31(16):5686-5692

26. Amoroso AJ, Coogan MP, Dunne JE, Fernandez-Moreira V, Hess JB, Hayes AJ et al (2007) Rhenium fac tricarbonyl bisimine complexes: biologically useful fluorochromes for cell imaging applications. Chem Commun 29:3066-3068

27. Wei L, Babich JW, Ouellette W, Zubieta J (2006) Developing the $\left\{\mathrm{M}(\mathrm{CO})_{3}\right\}^{+}$core for fluorescence applications: rhenium tricarbonyl core complexes with benzimidazole, quinoline, and tryptophan derivatives. Inorg Chem 45(7):3057-3066

28. Lakowicz JR (2006) Principles of fluorescence spectroscopy. Springer, Science Business Media, New York 
29. Ntziachristos V (2006) Fluorescence molecular imaging. Annu Rev Biomed Eng 8(1):1-33

30. Taylor DL, Salmon ED (1989) Basic fluorescence microscopy. Methods Cell Biol 29:207-237

31. Lo KK-W, Hui W-K, Ng DC-M (2002) Novel Rhenium(I) polypyridine biotin complexes that show luminescence enhancement and lifetime elongation upon binding to avidin. J Am Chem Soc 124(32):9344-9345

32. Lo KK-W, Hui W-K (2005) Design of rhenium(I) polypyridine biotin complexes as a new class of luminescent probes for avidin. Inorg Chem 44(6):1992-2002

33. Perera T, Marzilli PA, Fronczek FR, Marzilli LG (2010) NH NMR shifts of new structurally characterized fac- $\left[\operatorname{Re}(\mathrm{CO})_{3}(\text { polyamine })\right]^{\mathrm{n}+}$ complexes probed via outer-sphere hydrogen-bonding interactions to anions, including the paramagnetic $\left[\mathrm{Re}^{\mathrm{IV}} \mathrm{Br}_{6}\right]^{2-}$ anion. Inorg Chem 49:5560-5572

34. Abhayawardhana PL, Marzilli PA, Fronczek FR, Marzilli LG (2014) Complexes possessing rare "tertiary" sulfonamide nitrogen-to- metal bonds of normal length: $\mathrm{fac}_{-}\left[\mathrm{Re}(\mathrm{CO})_{3}(\mathrm{~N}(\mathrm{SO} 2 \mathrm{R})\right.$ dien) $] \mathrm{PF}_{6}$ complexes with hydrophilic sulfonamide ligands. Inorg Chem 53:1144-1155

35. Koullourou T, Natrajan LS, Bhavsar H, Pope SJA, Feng J, Narvainen J et al (2008) Synthesis and spectroscopic properties of a prototype single molecule dual imaging agent comprising a heterobimetallic rheniumgadolinium complex. J Am Chem Soc 130:2178-2179

36. Bartholoma M, Valliant J, Maresca KP, Babichc J, Zubieta J (2009) Single amino acid chelates (SAAC): a strategy for the design of technetium and rhenium radiopharmaceuticals. Chem Commun 5:493-512

37. Granifo J (1999) Mononuclear and binuclear rhenium(l) carbonyl complexes of 2,4,6-tris(2-pyridyl)-1,3,5-triazine (TPT), [\{ReCl(CO) $\left.\}_{n}(\mathrm{TPT})\right]$ $(n=1,2)$, and the formation of mixed-metal compounds with Re-TPT-M $\left(\mathrm{M}=\mathrm{Mn}{ }^{\prime \prime}, \mathrm{Co}\right.$ ", $\left.\mathrm{Cu}^{\prime \prime}\right)$ bonds. Polyhedron 18:1061-1066

38. Perera T, Fronczek FR, Marzilli PA, Marzilli LG (2010) Superbasic amidine monodentate ligands in $\mathrm{fac}$ - $\left[\operatorname{Re}(\mathrm{CO})_{3}\left(5,5_{0}-\mathrm{Me}_{2}\right.\right.$ bipy)(Amidine) $] \mathrm{BF}_{4} \mathrm{com}$ plexes: dependence of amidine configuration on the remote nitrogen substituents. Inorg Chem 49:7035-7045

39. Dattelbaum JD, Abugo OO, Lakowicz JR (2000) Synthesis and characterization of a sulfhydryl-reactive rhenium metal-ligand complex. Bioconjugate Chem 11(4):533-536
40. Fredericks SM, Luong JC, Wrighton MS (1979) Multiple emissions from rhenium(I) complexes: intraligand and charge-transfer emission from substituted metal carbonyl cations. J Am Chem Soc 101(24):7415-7417

41. Wrighton M, Morse DL (1974) Nature of the lowest excited state in tricarbonylchloro-1,10-phenanthrolinerhenium(I) and related complexes. J Am Chem Soc 96(4):998-1003

42. Záliš S, Milne CJ, El Nahhas A, Blanco-Rodríguez AM, van der Veen RM, Vlček A (2013) Re and Br X-ray absorption near-edge structure study of the ground and excited states of $\left[\operatorname{ReBr}(\mathrm{CO})_{3}(\mathrm{bpy})\right]$ interpreted by DFT and TD-DFT calculations. Inorg Chem 52(10):5775-5785

43. Chu W-K, Ko C-C, Chan K-C, Yiu S-M, Wong F-L, Lee C-S et al (2014) A simple design for strongly emissive sky-blue phosphorescent neutral rhenium complexes: synthesis, photophysics, and electroluminescent devices. Chem Mater 26(8):2544-2550

44. Zhou J, Gupta K, Aggarwal S, Aneja R, Chandra R, Panda D et al (2003) Brominated derivatives of noscapine are potent microtubule-interfering agents that perturb mitosis and inhibit cell proliferation. Mol Pharmacol 63(4):799-807

45. Skoog DA, West DM, Hollar FJ, Crouch SR (2004) Fundamentals of analytical chemistry. In: Harris D (ed), 8th edn. Brooks Cole-Thomson Learning, Belmont, USA

46. Olmsted J, Kearns DR (1977) Mechanism of ethidium bromide fluorescence enhancement on binding to nucleic acids. Biochemistry 16:3647-3654

47. He H, Lipowska M, Xu X, Taylor AT, Carlone M, Marzilli LG (2005) Re(CO) complexes synthesized via an improved preparation of aqueous fac$\left[\mathrm{Re}(\mathrm{CO})_{3}\left(\mathrm{H}_{2} \mathrm{O}\right)_{3}\right]^{+}$as an aid in assessing ${ }^{99 \mathrm{~m}} \mathrm{Tc}$ imaging agents. Structural characterization and solution behavior of complexes with thioetherbearing amino acids as tridentate ligands. Inorg Chem 44:5437-5446

48. Hudson L, Hay FC (1989) Practical immunology. 3rd edn. Oxford, London

49. Handunnetti SM, Kumara RR, Deraniyagala SA, Ratnasooriya WD (2009) Anti-inflammatory activity of methanolic leaf extract of Ixora coccinea. Pharmacognosy Res 1:80-90

\section{Submit your manuscript to a SpringerOpen ${ }^{\circ}$ journal and benefit from:}

- Convenient online submission

- Rigorous peer review

- Immediate publication on acceptance

- Open access: articles freely available online

- High visibility within the field

- Retaining the copyright to your article

Submit your next manuscript at springeropen.com 